http://jmscr.igmpublication.org/home/ ISSN (e)-2347-176x ISSN (p) 2455-0450

crossref DOI: https://dx.doi.org/10.18535/jmscr/v7i12.81

\title{
Changing Clinical and Biochemical Profile of Dengue Fever in Chittorgarh Region [Rajasthan]
}

\author{
Authors \\ Dr Anish Jain (M.D. Medicine) ${ }^{1^{*}}$, Dr Madhu Jain (M.D. Patho) ${ }^{2}$, \\ Dr Atul Khabya (MBBS) ${ }^{3}$, Somil Jain ${ }^{4}$ \\ ${ }^{1}$ HOD. Medicine Dist. Hospital Chittorgarh, ${ }^{2}$ Cyto- Oncologist \\ ${ }^{3}$ Asst. Dept. of Medicine, ${ }^{4}$ (M.B.B.S $2{ }^{\text {ND }}$ Year Student) RNT Medical College, Udaipur \\ *Corresponding Author \\ Dr Anish Jain (M.D. Medicine)
}

\begin{abstract}
Dengue is arboviral infection presenting with fever, arthalgia, headache, and rashes has spread to all tropical and subtropical countries. It is caused by arbovirus and transmitted by Aedes Ageypti and Aedes albopictus mosquitoes. There are four serotypes of dengue viruses [DEN1, DEN2, DEN3, DEN4] and DEN5 is also discovered. It causes wide spectrum of illness from mild asymptomatic illness to severe fatal dengue hemorrhagic fever. The WHO in 2009, also included neurological involvement in dengue infection. Objectives: To Review the changing trends in Dengue last two years in chittorgarh region.

Aim: To detect the presentation and complications of Dengue fever and impact of awareness in public about the disease.
\end{abstract}

Material and Methods: This study included 200 patients of age ranging 18-70yrs admitted in medical wards with fever at GOVT. Hospital, Chittorgarh, Rajasthan, India who had positive N S I/IgM positive. All were clinically examined, hematologic ally and biochemically tested and analyzed.

Results: We found that there is marked decrease in hemorrhagic dengue fever[DHF] and it complication in this area.

Keywords: D F, D H F, DSS Thrombocytopenia, leucopenia.

\section{Introduction}

Dengue is important arthropod borne disease worldwide. It causes 50 million dengue infections every year.

Dengue is an acute febrile illness that is caused by a flavivirus and vector is mosquito, that is Ades aegypti and Ades albopictus, that helps in spread. This disease is largely prevalent in tropical countries like India.
Dengue has varied clinical presentation often with unpredictable clinical progression and outcome. But the majority of patients recover following a non severe episode of illness, and very few patients progress to severe disease, like hematemisis and bleeding from other mucosal area. One case in our study progressed to G B syndrome. 
The Symptomatic dengue virus infection could be grouped in to

a. Undiffrenciated fever,

b. Dengue fever [DF]

c. Dengue haemorraghic fever [DHF]. Dengue haemorrghic fever is further classified in four severity grades (i-iv), with grades III and IV being defined as dengue shock syndrome [DSS].

The balanced approach to case management, early patient awareness and diagnosis leads to drastic decrease in complications in this region, which is a positive sign for community health to reduce morbidity and mortality.

\section{Material and Methods}

This prospective observational study was done in medical ward of a secondary referral care centre in Chittorgarh [Rajsthan, India], has population of 15 lakhs (2011 CENSUS). The climate here is hot and semi arid. Patients aged 18 to 70 years were included in the study. Only Dengue [S D BIOSENSOR, DUO COMBO DEVICE] card was used for diagnosis. Out of these only 5 cases were positive with other concomittent illness like scrub thypus thyphoid and tuberculosis. All patients under study were undergone haematological and biochemical tests (CBC PBF, $X$ ray Chest, Renal and Liver Function Tests, electrolytes profile and serological test for fever [Thyphoid, Dengue, chikanguniya etc])

\section{Results}

- Out of 200 confirmed cases majority of patients were from 18 to 60 yrs [table 1]. The fever [3] was commonest symptom in around $100 \%$, and lasted for 3to 4 days, headache was in $100 \%$, nausea and vomiting were in $50 \%$, rashes in $5 \%$, Myalgia in $40 \%$.

- Pain abdomen in $70 \%$ and around $3 \%$ of patients had bleeding complication including hematemesis. Only one patient had neurological complication that is $\mathrm{G} B$ syndrome.

- Hepatomegaly was presented in $30 \%$, spleenomegaly in $5 \%$ and serositis in $10 \%$, out of these pleural effussion in $9 \%$ and ascities in $1 \%$ patients.

- $15 \%$ Patients had S B P $<90 \mathrm{mmHg}$ and recovered with oral and intravenous fluid. No DIC and ARDS were found in our study.

Table 1: Gender and age distribution

\begin{tabular}{|l|c|c|c|c|}
\hline Age & $18-30$ & $30-45$ & $46-60$ & $>60$ \\
\hline Male & 30 & 45 & 25 & 4 \\
\hline Female & 28 & 40 & 24 & 4 \\
\hline Total & 58 & 85 & 49 & 8 \\
\hline
\end{tabular}

Table 2: Clinical Features

\begin{tabular}{|l|c|c|c|c|c|}
\hline Clinical features & No of Patients & $\%$ & Clinical features & No of patients & $\%$ \\
\hline Fever & 200 & 100 & Pleural effusion & 18 & 9 \\
\hline vomiting & 100 & 50 & SBP<90mmhg & 30 & 15 \\
\hline Pain abdomen & 140 & 70 & Breathlessness & $2 \%$ & 20 \\
\hline Headache & 200 & 100 & ARDS & 0 & 0 \\
\hline Spleenomegaly & 10 & 5 & DIC & 0 & 0 \\
\hline Myalgia & 80 & 40 & Neural complication & 1 & $0.5 \%$ \\
\hline Rash & 10 & 5 & Rashes & 5 & $2.5 \%$ \\
\hline Ascities & 2 & 1 & & & \\
\hline Hepatomegaly & 60 & 30 & & & \\
\hline
\end{tabular}

Table -3 Bleeding Manifestation

\begin{tabular}{|l|c|c|}
\hline Bleeding Tendency & No of patients & $\%$ \\
\hline Haemtemesis & 1 & 0.5 \\
\hline
\end{tabular}


Table 4: Laboratory parameters

\begin{tabular}{|c|c|c|}
\hline Parameters & $\begin{array}{c}\text { No of } \\
\text { Patients }\end{array}$ & $\%$ \\
\hline SGPT >35 I U /L & 150 & $75 \%$ \\
\hline Elevated three times normal & 30 & $15 \%$ \\
\hline SGOT >35I U /L & 160 & $80 \%$ \\
\hline Elevated three times normal & 80 & $40 \%$ \\
\hline \multicolumn{3}{|l|}{ ALP [Normal in all patients } \\
\hline \multicolumn{3}{|l|}{ Thrombocytopenia } \\
\hline$<30,000 /$ cumm & 100 & $50 \%$ \\
\hline$<80,000 /$ cumm & 50 & $25 \%$ \\
\hline 80-130,000/cumm & 50 & $25 \%$ \\
\hline \multicolumn{3}{|l|}{$\mathrm{Hb}$ [normal in all patients] } \\
\hline TLC $<4000 /$ cumm & 30 & $15 \%$ \\
\hline 4000-6000/cumm & 170 & $85 \%$ \\
\hline Hyponatraemia[<130mEq/L] & 10 & $5 \%$ \\
\hline Hypokalaemia & 20 & $10 \%$ \\
\hline $3.5-3.0 \mathrm{mEq} / \mathrm{L}$ & & \\
\hline $3.0-2.5 \mathrm{mEq} / \mathrm{L}$ & 4 & $2 \%$ \\
\hline Creatinine $>1.5 \%$ & 8 & $4 \%$ \\
\hline Urea $>45 \%$ & 10 & $5 \%$ \\
\hline Chest Xray effusion & 2 & $1 \%$ \\
\hline $\begin{array}{l}\mathrm{U} S \mathrm{~S} \text { free fluid in pleural } \\
\text { (minimal) and peritoneal cavity }\end{array}$ & $18+2=20$ & $10 \%$ \\
\hline
\end{tabular}

Table 4 shows that liver function test was elevated in most of cases. Although alkaline phosphates was normal in all cases. The haematological parameters shows that leucopenia was present in $15 \%$.

Thrombocytopenia- counts less than 30,000/cumm was in $50 \%$ cases and $<80,000$ was in $25 \%$ and in $25 \%$ it was to $80,000-130,000 /$ cumm, at time of admission. Electrolyte imbalance mainly hypokalemia found in was in $10 \%$ and only $2 \%$ patients had potassium $<2.5 \mathrm{meq} / \mathrm{L}$.Hyponatermia was seen in $5 \%$ cases.

The weakness in both lower limb which proceed to $\mathrm{G} B$ syndrome during course of disease was seen in one case. On Xray chest and ultra sound serositis seen In $10 \%$ cases.

\section{Discussion}

Dengue is emerging major viral acute febrile disease now a days with varied clinical symptoms and changing haemato- biochemical values. The current study showed that here in our chittorgarh region last two years decreasing dengue haemorraghic fever and reduced other complication is good sign of herd immunity due to its endemecity and public awareness and early and prompt diagnosis by physicians and accessible lab test like Dengue combo test and ELISA.

In our study the gender ratio is almost equal, although males are more affected [52\% are male as compared to females $49 \%$ ]

The fever is almost present in $100 \%$ cases, which was similar to other Studies ${ }^{[5]}$. Headache was present in $100 \%$ cases., varied from study of Kumar et $\mathrm{al}^{[6]}$, they found less percentage .The gastrointestinal symptoms were next major presentation, nausea, vomiting and pain abdomen seen in $50-75 \%^{[6]}$, and very well managed earliest to prevent further complications. The other infectious disease like scrub typhus, typhoid also prevalent in this region and excluded by card test..The liver injury in dengue may be due to direct effect of the virus or host immune response on liver cells or localized leakage inside liver ${ }^{[7]}$ [japi,3,4] LIKHNA.

Haemetmesis and petchieal rashes were the only Bleeding manifestations, these were due to low platelet count, here we found that the platelet counts in most cases was below 80,000/cumm and does not correlate between bleeding tendencies. ${ }^{[8]}$, not a single patient was transfused the platelet concentrate even their count was less than 10,000/cumm. All thrombocytopenic patients recovered within 3-7 days of admission. The leucopenia may be due to acute bone marrow suppression may be by virus induced. In our study leucopenia [count $<4,000 /$ cumm] found in only 15 $\%$ cases. While in other study Itoda et al and others study [Ageep et al] ${ }^{[9]}$, leucopenia was detected in $71 \%$ cases. This is a changing scenario in our region in last two years similar to ,Mittal et $\mathrm{al}^{[10]}$ who found leucopenia in $19.2 \%$ of cases.

Hypotension; S B P <90mmHg found in $15 \%$ caes and respond well to intravenous fluids.

Electrolyte imbalance is also seen in dengue fever Hypokalemia $[<3.5-2.5 \mathrm{mEq} / \mathrm{L}] \mathrm{seen}$ in $24 \%$ and Hyponatraemia was in 5\%patients, but we did not find symptomatic hypokalemia. Hypontraemia was attributed due to increased antidiuretic harmone levels and, and hypokalemia was due to increased renal excreation of potassium due to 
activation of rennin angiotensin aldosterone mechanism secondary due to volume depletion ${ }^{[1]}$ Serosities is mainly caused by capillary leak because of host and virus interaction causes, vascular endothelial changes and transient imbalance of inflammatory mediators like cytokines and chemokines.

We found in our study ascities in $1 \%$, pleural effusion in $9 \%$ on ultrasonography. The creatinine was raised only in $4 \%$ of cases and was $>1.5 \mathrm{mg} / \mathrm{dl}$, not complicating the course of disease. Liver dysfunction was universal almost in all patients. It varies from mild to moderate liver injury. The ALT is increased more than three times of normal found in $15 \%$ and AST was more than three time normal seen in 40\%.The $75 \%$ cases Alanine transaminase [ALT] had raised $>35 \mathrm{U} / \mathrm{L}$, whereas in $80 \%$ patients Aspartate transaminase $[\mathrm{AST}]>35 \mathrm{U} / \mathrm{L}$. The sign of liver failure was not observed in any patient. Deprivation of oxygen leads to injury of liver parenchyma which releases transaminase correlate the degree of hepatocellular injury but without any association with prognosis. ${ }^{[12,13]}$

One patient had neurological involvement during course of disease as Guillain Barre syndrome [GBS], diagnosed on the basis of clinical sign and symptom .He felt difficulty in passing urine first and then difficulty in walking which progressed to both lower limb paraesis. $\mathrm{He}$ was given methylprednisalone one gram I V then he was reffered to tertiary center on day 3., where he was diagnosed as G B syndrome. Then he recovered completely within 30 days.

In our study the complication like ARDS, DIC were not seen. Only one patient had Haemetemesis who was reffered to Tertiary care centre. Mortality rate in our study was nil..Our study shows that there are changes in clinical and laboratory parameters and there is decrease in case fatality rate.

These features are contributed by the increased awareness of disease and consequent improved diagnosis and management, that separate this chittorgarh region from other regions of Rajasthan in last two years.

\section{Limitation of our study}

Nerve Conduction study and serotyping of Dengue Virus could not be done at our place.

\section{Conclusion}

As in other tropical countries, in India Dengue is emerging as major acute febrile illness now a days and it is big threat to human life. Although it is endemic in our region as well in Rajasthan. Due to presence of other acute febrile conditions like malaria, scrub typhus, Enteric fever in this region with common manifestations in all above mention disease, contributes a difficulty in diagnosis of dengue fever. But with high clinical suspicion \& early diagnosis with S D biosensor Dengue combo Test has lead to reduced complication and early recovery and low fatality in our region in last two years. There is havoc in society for platelet transfusion but optimal care of patient's vitals and hydration minimize the possibility of platelet transfusion.

\section{References}

1. Kasper DL, fauci AS, Hauser SL. et al. Arthropod-borne and rodent-borne virus infections. In: Harrison's principles of internal Medicine, $19^{\text {th }}$ edition [Vol2] .New York; McGraw-Hill Education 2015;P.1306

2. National Vector Borne Disease control Programme. Dengue /dengue haemorraghic fever.2015;

3. World Health Organization ROFSA. Comprehensive guidelines for prevention and control of dengue and dengue haemorraghic fever .2011;

4. Dengue: Mohan DK, Shiddappa M, Dhanajaya .A study of clinical profile of dengue fever in a tertiary care teaching hospital .Sch J App Med Sci.2013:1[2802]. 
5. Rachel D, Rajamohana, Philip AZ .A study of clinical profile of dengue fever in kollam. Kerla India, Dengue Bull. 2005;29:197-202.

6. Nimmagadda SS, Mahabala C, Boloor A, Raghuram PM, Nayak UA.

7. Atypical Manifestations of Dengue Fever [DF]- Where Do We Stand Today? J Clin Diagn Res.2014;8[1] :71-3[DOI] [PubMed]

8. Itha S,Kashyap R, Krishnani N, Saraswat VA, Choudhuri G, Aggarawal R. Profile of liver involvement in dengue virus infection .Natl Med J India 2015;18:127.

9. Fernando S, W ijewickrama A, Gomes N,et al. Patterns and Causes of Liver Involvement In Acute Dengue Infection.B MC Inf Dis $2016 ; 16: 319$

10. Seema A, Singh V, Kumar S,Kumar A, Dutta S. The changing clinical spectrum of dengue fever in 2009 epidemic in north india : A tertiary teaching hospital based study. J Clin Diagn Res. 2012 ;6 [6]: 9991002

11. Schexneider ki, Reedy EA. Thrombocytopenia in Dengue. Current Hematology Reports2005;4:145-8.

12. Lumpaopong A, Kaewplang P, Watanaveeradej et al. Electrolyte Disturbances and abnormal urine analysis in children with dengue infection. Southeast Asian J trop Med public health 2010; 41:72-6

13. Francisa R F. Gurreiro A, Romellia PG, et al. dengue profile of Haematological and biochemical dynamics. Rev Bras Hematol Hemoter 2012; 34:36-41

14. Souza LJ,ALVE Sjg, Nogueria R M ,et al. Aminotransferase changes and acute hepatitis in patients with dengue fever: analysis of 1585 cases. Braz J Infect Dis 2004;8:156-63. 